\title{
IDENTIFICATION OF GABA-PRODUCING LACTIC ACID BACTERIA FROM CINCALOK FERMENTATION BASED ON THE 16S RRNA AND GAD GENES
}

\author{
ADHITYA NAUFAL PRIBADHI ${ }^{1 *}$, ENDANG KUSDIYANTINI², REJEKI SITI FERNIAH ${ }^{2}$ \\ ${ }^{1}$ Faculty of Medicine, Wahid Hasyim University, Jl. RW Sugiarto No. 1, Mount Pati Semarang, Central Java, Indonesia. ${ }^{2}$ Departement of \\ Biology, Faculty of Science and Matematics, Diponegoro University, Jl. Prof. Soedarto, SH, Tembalang Semarang, Central Java, Indonesia. \\ Email: adhityanaufal7@gmail.com
}

Received: 27 January 2021, Revised and Accepted: 02 June 2021

ABSTRACT

Objective: The research to identify LAB using $16 \mathrm{~S}$ rRNA potential as high produce GABA and design primer can amplify that gad gene.

Methods: Isolation genomic form LAB, molecular identification based 16S rRNA, design primer use primer3plus, and use application serial cloner to ensure the primer can amplify to target gene.

Results: Lactic acid bacteria that have been analyzed based on the 16 S rRNA gene have the highest similarity with Weissella confusa strain JCM 1093 with a similarity of $98.38 \%$. the results of the analysis based on the gad gene using several primers that have been designed by researchers and based on existing references are unable to amplify the gad gene owned by $W$. confusa.

Conclusion: The results of the analysis based on the 16S rRNA gene for lactic acid bacteria were obtained by Weissella confusa. However, for the results of identification analysis based on the gad gene, the designed primers were unable to amplify the gad gene in $W$. confusa.

Keywords: Cincalok, Glutamate decarboxylase, Lactic acid bacteria, 16S rRNA.

(C) 2021 The Authors. Published by Innovare Academic Sciences Pvt Ltd. This is an open access article under the CC BY license (http://creativecommons.org/ licenses/by/4.0/) DOI: http://dx.doi.org/10.22159/ajpcr.2021v14i7.40881. Journal homepage: https://innovareacademics.in/journals/index.php/ajpcr

\section{INTRODUCTION}

Fermented foods in Indonesia are very diverse, from Sabang to Marauke seasoning and how to process fermented food obtained from our ancestors. Fermented foods such as Cincalok are fermented foods originating from West Kalimantan made from small shrimp. Shrimp has a nutritional content in the form of protein; this protein will later be used as a substrate in the fermentation process using microbes. One microbe plays a role, namely, lactic acid bacteria (LAB). One of the bakeries found by Achmad et al. [1] in Cincalok is Lactobacillus RED1.

Cincalok fermented food contains LAB which consists of various species. Research on the species that produce GABA requires identification. Identification of lactic acid bacterial species can be done in various ways through morphological characteristics, metabolites, phenotypes, and genotypes. Phenotypic identification is considered inaccurate, and there is a fear of misidentification. A combination of identification methods will provide better results, for example, a combination of morphological and genetic identification. In general, the identification of microbes uses molecular analysis of $16 \mathrm{~S}$ and 23S rRNA [2]. The choice of $16 \mathrm{~S}$ rRNA as a reference in identifying a microbe is because it has a base sequence of 1500-1550 base pairs. Furthermore, the analysis with $16 \mathrm{~S}$ rRNA had a conservative base sequence, so that it can be a reference for making phylogeny trees [3].

Glutamate decarboxylase is considered to be responsible for the production of GABA through strains of GABA-producing lactic acid bacteria, such as Lactobacillus and Lactococcus. The glutamate decarboxylase has been isolated from various sources and its biochemical properties are known. Lactobacillus brevis had been isolated by GAD and determined its biochemical characterization. The research that has been done is to characterize GAD and clone the gad gene in Lactococcus lactis and found that L. lactis contains only one gad gene. Although GAD is widely distributed in BAL, the ability to produce GABA varies greatly among LAB [4].
The genetic identification method for LAB that is commonly used is the analysis of GAD gene sequencing. Glutamate decarboxylase enzyme (GAD) irreversibly via -decarboxylation of L-glutamic acid to produce GABA, which the enzyme depends on pyridoxal 5-phosphate. Glutamate decarboxylase is widely distributed in eukaryotes and prokaryotes. The research that has been done shows that GAD is present in LAB. Overall GABA can provide resistance to bacterial cells under acidic conditions and the GAD decarboxylation process has been combined with the energy synthesis found in Lactobacillus sp. Strain E1 [5].

This study aims to determine the species names of LAB and those previously isolated, tested biochemically and also analyzed for GABA content using the thin-layer chromatography method [6].

\section{METHODS}

\section{Sample and materials}

This study used materials in the form of cincalok, MRSA media, $\mathrm{CaCO}_{3}$, Phosphate Buffer Saline (PBS), $\mathrm{ddH}_{2} \mathrm{O}$, chelex, Dream Taq Green PCR Master Mix, agarose gel, aquades, Buffer TAE, primer forward 16S rRNA 27F (5'-AGAGTTTGATCMTGGCTCAG-3'), primer reverse 16S rRNA 1492R (5'-TACGGYTACCTTGTTACGACTT-3'), primer forward gad (5'- ATGGGCATCACTTATACTGG-3' dan 5'-CARGTNTGYTGGGARAA-3'), primer reverse gad (5'-TTTAGGTTGCGGATCACTAT-3', 5'-CGATCGGATAAATCGTAGAG-3' dan 5'-GGRTANACNARNCCRTAYTTRT'-3'), DNA template, marker (DNA ladder), alcohol 70\%, loading dye.

\section{DNA isolation and purification}

DNA isolation using the Chelex method [7]. LAB isolates that produced the highest GABA were taken as much as 2 ose and put into a $1.5 \mathrm{~mL}$ microtube. The addition of $100 \mu \mathrm{L} \mathrm{ddH}_{2} \mathrm{O}$ to LAB. $1 \mathrm{~mL}$ of phosphate buffer saline (PBS) was added, and then incubated for $24 \mathrm{~h}$ at $4^{\circ} \mathrm{C}$. Furthermore, the extraction was carried out by centrifugation at a speed of $12,000 \mathrm{rpm}$ for 10 minutes. The results obtained are in the 
form of natan and supernatant layers. The layer of the supernatant will be removed with a micropipette which aims to remove saponins without damaging the pellets.

The next step was adding $1 \mathrm{ml}$ of $\mathrm{ddH}_{2} \mathrm{O}$ and centrifuged at $12,000 \mathrm{rpm}$ for $5 \mathrm{~min}$, the supernatant was discarded. $\mathrm{LAB}$ was added with $\mathrm{ddH}_{2} \mathrm{O}$ as much as $100 \mu \mathrm{L}$ and $50 \mu \mathrm{L} 20 \%$ chelex 100 . The chelex solution was shaken so that the crystals could be lifted. Chelex should be added in cold conditions. The solution is heated on a hot plate for $10 \mathrm{~min}$ centrifugation again at a speed of $12,000 \mathrm{rpm}$ for $10 \mathrm{~min}$. The supernatant obtained was taken with a micropipette and separated from the pellets. The supernatant containing the DNA genome was transferred to another microtube. Samples are stored in the freezer at $-20^{\circ} \mathrm{C}$, if not used immediately. Quantitative DNA test to determine the purity and concentration of each DNA sample was measured using nanodrops.

\section{Molecular identification of the $16 \mathrm{~S}$ rRNA coding gene}

Theprimersusedinthisstudywere27F(5'-AGAGTTTGATCMTGGCTCAG-3') and 1492R (5'- TACGGYTACCTTGTTACGACTT -3'). DNA amplification by PCR was carried out using the GeneAmp PCR System 9700 thermal cycler. The initial stage of amplification began with the manufacture of PCR mix with a total volume of $25 \mu \mathrm{l}$ consisting of $1 \mu \mathrm{L} 27 \mathrm{~F}$ primer, $1 \mu \mathrm{l} 1492 \mathrm{R}$ primer, $12.5 \mu$ l Thermo Fisher Scientific's Dream Taq PCR, and 9.5 $\mu \mathrm{L}$ $\mathrm{ddH}_{2} \mathrm{O}$. This mixing is done on a microtube. PCR was performed starting from the predenaturation stage at $94^{\circ} \mathrm{C}$ for $4 \mathrm{~min}$. 35 PCR cycles occurred on the separation of DNA strands (denaturation) at $94^{\circ} \mathrm{C}$ for $1 \mathrm{~min}$, primary attachment (annealing) at $56^{\circ} \mathrm{C}$ for $1 \mathrm{~min}$, and the extension stage at $72^{\circ} \mathrm{C}$ for $1 \mathrm{~min}$. The amplification process was ended with a onestep extension at $72^{\circ} \mathrm{C}$ for $5 \mathrm{~min}$ and storage at a final stage of $4^{\circ} \mathrm{C}$. DNA PCR products were separated by electrophoresis on 1\% (wt/volume) agarose gel. The DNA sequencing results were sent to Macrogen through PT. Indolab Utama.

\section{Molecular identification of the gad gene}

Primers are designed using the Primer3Plus application and refer to references to identify the gad gene. The primary pairs are shown in Table 1.

The molecular identification of the gad gene requires a primary design; the primary design used is Primer3Plus. The primary design is needed to obtain a primer that can amplify DNA using the PCR method; in the primary design process an in silico stage is needed. In silico, the primary design with the help of computer software, in this study using Serial Cloner software.

A primer designed in this study to amplify the gad gene. Gad gene is a gene that plays a role in the process of forming GABA. The selection of molecular identification on the gad gene will be used to identify the species level based on the gad gene.

\section{Sequencing}

Data in the form of base sequences from forward and reverse primers that have been obtained from PT. Indolab processed using BioEdit. The sequencing results obtained will later be compared with other species in the NCBI application (http://blast.ncbi.nlm.nih.-gov) through the BLAST (Basic Local Alignment Search Tool) process.

\section{Phylogenetic tree}

The next stage after sequencing analysis, the data obtained will be aligned (Clustal W) making phylogenetic trees using MEGA X software, the method chosen by the neighbor-joining tree p-distance model.

\section{RESULTS}

\section{Molecular identification of LAB based on $16 \mathrm{~S}$ rRNA}

CIN-1 isolate was able to produce the highest GABA concentration in the previous studies [6], then it will be identified molecularly based on analysis of the $16 \mathrm{~S}$ rRNA gene. The primers used were $27 \mathrm{~F}$ and $1492 \mathrm{R}$ primers, so that the amplification results were obtained as shown in Fig. 1. The sequences obtained from the 16S rRNA analysis were analyzed using a phylogenic tree and obtained in Fig. 2.
Molecular identification of LAB based on the gad gene

Primers for identifying gad genes in Cin-1 isolates were designed using primer3plus and based on reference (Table 1). Primers that have been designed were tested using the Serial Cloner application, with the experimental sample in the form of a gad gene from the bacteria Lactobacillus brevis BH2 glutamate decarboxylase (Figs. 3 and 4). The results of amplifying the gad gene using a primer that had been designed were unable to amplify the gad gene owned by W. confusa (Fig. 5).

\section{DISCUSSION}

Molecular identification of LAB based on 16S rRNA

Quantitative measurements and purity of DNA were carried out using a nanodrop 2000 UV-VIS spectrophotometer. According to Pelt-Verkuil et al. [8], DNA concentration was determined by absorbance measurement at $260 \mathrm{~nm}$. The absorbance ratios of $260 \mathrm{~nm}$ and $280 \mathrm{~nm}(\mathrm{~A} 260 / 280)$

Table 1: The primary design used for the amplification of the GAD gene

\begin{tabular}{lll}
\hline Name & $\mathbf{5 - 3}$ 'sequence & Information \\
\hline Gad-F & ATGGGCATCACTTATACTGG & Primer3Plus \\
Gad-R1 & TTTAGGTTGCGGATCACTAT & Primer3Plus \\
Gad-R2 & CGATCGGATAAATCGTAGAG & Primer3Plus \\
F3 & CARGTNTGYTGGGARAA & Komatsuzaki et al., 2014 \\
R6 & GGRTANACNARNCCRTAYTTRTG & Komatsuzaki et al., 2014 \\
\hline
\end{tabular}

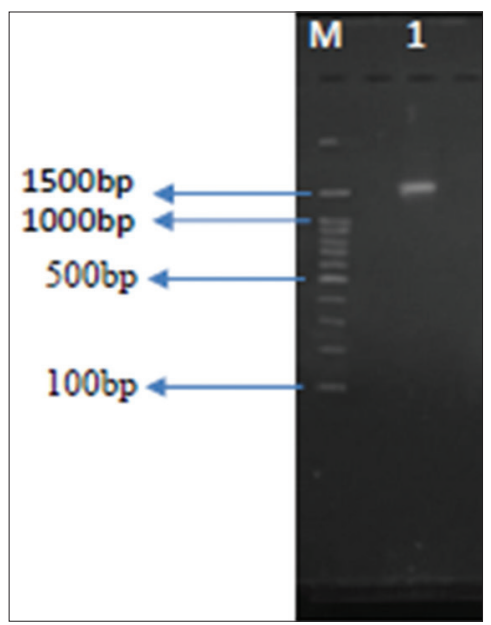

Fig. 1: Visualization of the amplification of the $16 \mathrm{~S}$ rRNA gene encoding M. Marker 100 bp ladder, 1. CIN-1 isolate

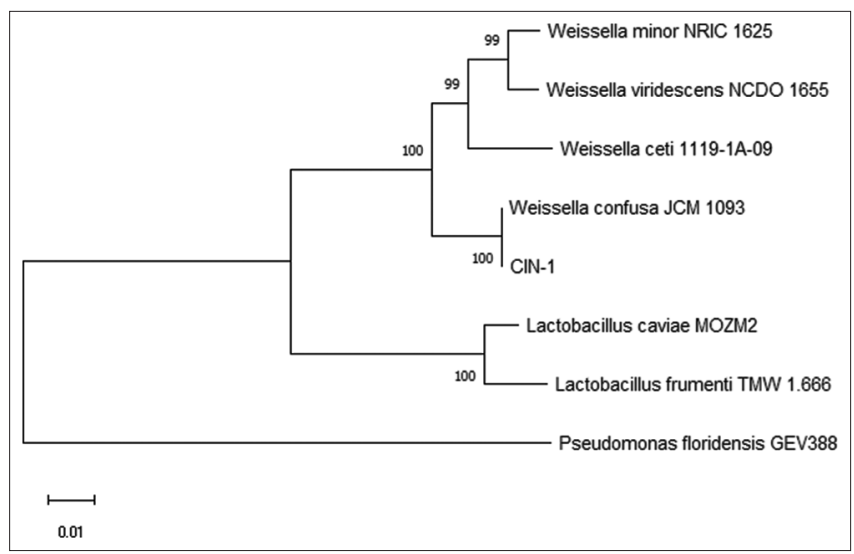

Fig. 2: Phylogenetic trees based on the $16 \mathrm{~S}$ rRNA gene of CIN-1 isolates using Neighbor-Joining analysis and Bootstrap 1000 replicates phylogeny test 
are commonly used to measure the contamination of dissolved DNA to RNA and protein. DNA purity was obtained from the absorbance ratio A260/280. According to Sambrook and Russell [9], A260/280 ratio <1.8 indicates protein contamination in the DNA extract obtained. Good DNA purity is indicated by the ratio A260/280 between 1.8 and 2.0.

The quantitative results of DNA extraction are shown in Table 2. The quantitative test of CIN-1 DNA extract shows a DNA concentration of $182.1 \mathrm{ng} / \mu \mathrm{l}$ with a DNA purity of 2.15 in the ratio A260/280. The results of the DNA purity and concentration analysis indicated that the DNA isolation method in this study was able to isolate DNA from CIN-1 isolates.

The results of $16 \mathrm{~S}$ rRNA gene amplification were analyzed by agarose gel electrophoresis. The marker used to compare the size of the DNA in the amplification results was $100 \mathrm{bp}$ ladder. The results of 16S rRNA gene amplification from CIN-1 DNA showed the presence of DNA bands with a length range of $1500 \mathrm{bp}$ in the agarose gel electrophoresis results (Fig. 1). According to Patel [10], the 16S rRNA gene has a length of 1522 bp in bacteria and can be used to determine the phylogeny and taxonomy of bacteria. The DNA amplification product is followed by a sequencing process.

Sequencing of CIN-1 DNA amplification aims to obtain information on the base sequence of the target DNA amplified by PCR with a certain length. The sequencing data obtained are aligned using the Basic Local Alignment Search Tools (BLAST) on the NCBI website. The program shows areas of local similarity between the sequences examined with a stored sequence information database to calculate statistical significance of match.

The result of CIN-1 isolate sequencing had a Query Length of $1362 \mathrm{bp}$. The BLAST results showed that the CIN-1 isolate had the highest similarity to Weissella confusa strain JCM 1093 with a similarity of 98.38\% (Table 3). The percentage identification value above $97.5 \%$ can be stated as having a similarity at the species level, while the percentage

Table 2: DNA quantification results at OD 260/280

\begin{tabular}{llll}
\hline S. No. & Sample & DNA concentration $\mathbf{n g} / \boldsymbol{\mu l}$ & $\mathbf{A 2 6 0 / 2 8 0}$ \\
\hline 1. & CIN-1 & 182.1 & 2.15 \\
\hline
\end{tabular}

Table 3: Homologous sequences of alignment results with $16 \mathrm{~S}$ rRNA from CIN-1 bacterial isolates

\begin{tabular}{llllll}
\hline Description & $\begin{array}{l}\text { Max } \\
\text { Score }\end{array}$ & $\begin{array}{l}\text { Total } \\
\text { Score }\end{array}$ & $\begin{array}{l}\text { Query } \\
\text { Cover (\%) }\end{array}$ & E value & $\begin{array}{l}\text { Per. ID } \\
\text { (\%) }\end{array}$ \\
\hline $\begin{array}{l}\text { Weissella confusa } \\
\text { JCM 1093 }\end{array}$ & 2412 & 2412 & 100 & 0.0 & 98.38 \\
$\begin{array}{l}\text { Weissella cibaria } \\
\text { II-I-59 }\end{array}$ & 2357 & 2357 & 100 & 0.0 & 97.58 \\
$\begin{array}{l}\text { Weissella oryzae } \\
\text { SG25 }\end{array}$ & 2209 & 2209 & 98 & 0.0 & 96.19 \\
$\begin{array}{l}\text { Weissella hellenica } \\
\text { NBRC 15553 }\end{array}$ & 2187 & 2187 & 98 & 0.0 & 95.77 \\
$\begin{array}{l}\text { Weissella } \\
\text { paramesenteroides }\end{array}$ & 2187 & 2187 & 98 & 0.0 & 95.84 \\
$\begin{array}{l}\text { NRIC 1542 } \\
\text { Weissella bombi }\end{array}$ & 2180 & 2180 & 98 & 0.0 & 95.62 \\
$\begin{array}{l}\text { R-53094 } \\
\text { Weissella soli Mi268 }\end{array}$ & 2169 & 2169 & 99 & 0.0 & 95.41 \\
$\begin{array}{l}\text { Weissella viridescens } \\
\text { NRIC 1536 }\end{array}$ & 2165 & 2165 & 100 & 0.0 & 95.08 \\
$\begin{array}{l}\text { Weissella } \\
\text { diestrammenae } \\
\text { ORY33 }\end{array}$ & 2145 & 2145 & 99 & 0.0 & 95.50 \\
$\begin{array}{l}\text { Weissella uvarum } \\
\text { B18NM42 }\end{array}$ & 2137 & 2137 & 100 & 0.0 & 94.71 \\
\hline & & & & & \\
\hline
\end{tabular}

identification value above $95 \%$ can be stated as a similarity at the genus level [11].

The alignment result also shows the same max score and total score, namely, CIN-1 of 2412. E-value 0.0 indicates a significant alignment. The relationship between species was analyzed using phylogenetic tree development using the MEGA X program. Phylogenetic trees of CIN-1 isolates were analyzed using the Neighbor Joining (NJ) method (Fig. 2).

These results indicated that the CIN-1 isolate had a bootstrap value of 100 with Weissella confusa JCM 1093. The bootstrap value of 100 indicated that in 1000 replications the same 1000 trees were formed. According to Hidayat and Pancoro [12], bootstrap analysis is a method that tests how well the model data set is and this value is usually located in the branches of a phylogenetic tree. Bootstrap value categories include high $(>85 \%)$, moderate $(70-85 \%)$, weak $(50-69 \%)$, or very weak $(<50 \%)$ [13]. A phylogenetic tree with a 0.01 scale bar shows a genetic distance with a change in nucleotides of 1 base in every $100 \mathrm{bp}$. Based on the observation result, CIN-1 isolate bacteria have stem cell morphology and Gram stain is Gram positive, and the catalase test is catalase negative. According to Fusco et al. [14], W. confusa are Grampositive and catalase Gram-negative bacteria. The cells of these bacteria are short rods. These bacteria are heterofermentative and produce D and $\mathrm{L}$ lactic acid enantiomers when fermenting glucose. This bacterium is able to grow at temperatures of $45^{\circ} \mathrm{C}$ in several strains. Research that has been conducted by Thapa et al. [15], W. confusa can be found in fish-based traditional foods from the East Himalayas and other studies from [16], these bacteria are also found in fermented foods from freshwater fish originating from Thailand.

\section{Molecular identification of LAB based on the gad gene}

The primary design obtained from the application of Primer3Plus is the primary gad-F 5'-ATGGGCATCACTTATACTGG-3 'and the reverse gad-R1 5'-TTTAGGTTGCGGATCACTAT-3' and gad-R2 5'-CGATCGGATAAATCGTAGAA-3 'primer. Gad-F, gad-R1, and gad-R2 primers will attach to bases 634,1386 , and 1193, respectively, on the Lactobacillus brevis $\mathrm{BH} 2$ glutamate decarboxylase DNA. This gad-F primer has a base length of $20 \mathrm{bp}$, Tm 55 oC, and GC 45\%. The reverse gad-R1 primer has a base length of $20 \mathrm{bp}$, a Tm of $54.9 \mathrm{oC}$, and a GC of $45 \%$, while the primary gad-R2 has a base length of $20 \mathrm{bp}$, Tm of 55 oC, and GC of $45 \%$.

Other primers adjusted according to the journal [17] are forward primers with code F3 5'-CARGTNTGYTGGGARAA-3 'and reverse primers with code R6 5'-GGRTANACNARNCCRTAYTTRTG-3'. Primary F3 has a base length of $17 \mathrm{bp}$ and $\mathrm{Tm}$ of $45.1^{\circ} \mathrm{C}$ while primer R6 has a length of $23 \mathrm{bp}$ and $\mathrm{Tm}$ of $53.9^{\circ} \mathrm{C}$.

Software used in in silico, namely, Serial Cloner. The Lactobacillus brevis $\mathrm{BH}$ glutamate decarboxylase DNA sequence was opened through the software. The in silico results in the software using gad-F primer as forward primer and gad-R1 as reverse obtained 753 bp PCR products. The amplification results of the two primers are shown in Fig. 3. The results of in silico PCR products using F-3 primer and R-6 primer on Lactobacillus brevis BH glutamate decarboxylase obtained 526 bp PCR products are shown in Fig. 4.

The amplification of the gad gene using PCR with primary variations did not produce results even though in silico could be done. Result electrophoresis is shown in Fig. 5.

Primers that cannot amplify DNA can be caused by several factors. According to Borah [18], a good primer has a base length between 18 and 30 oligonucleotides, with this length expected to bind the template at a specific annealing temperature. If the primer is too short it can affect the specificity of the primer so that the primer will have difficulty sticking to the template. The percentage of GC should be in the range of $40-60 \%$, a percentage of GC that is too low can reduce the efficiency of the PCR process because the primers cannot compete to stick to the 


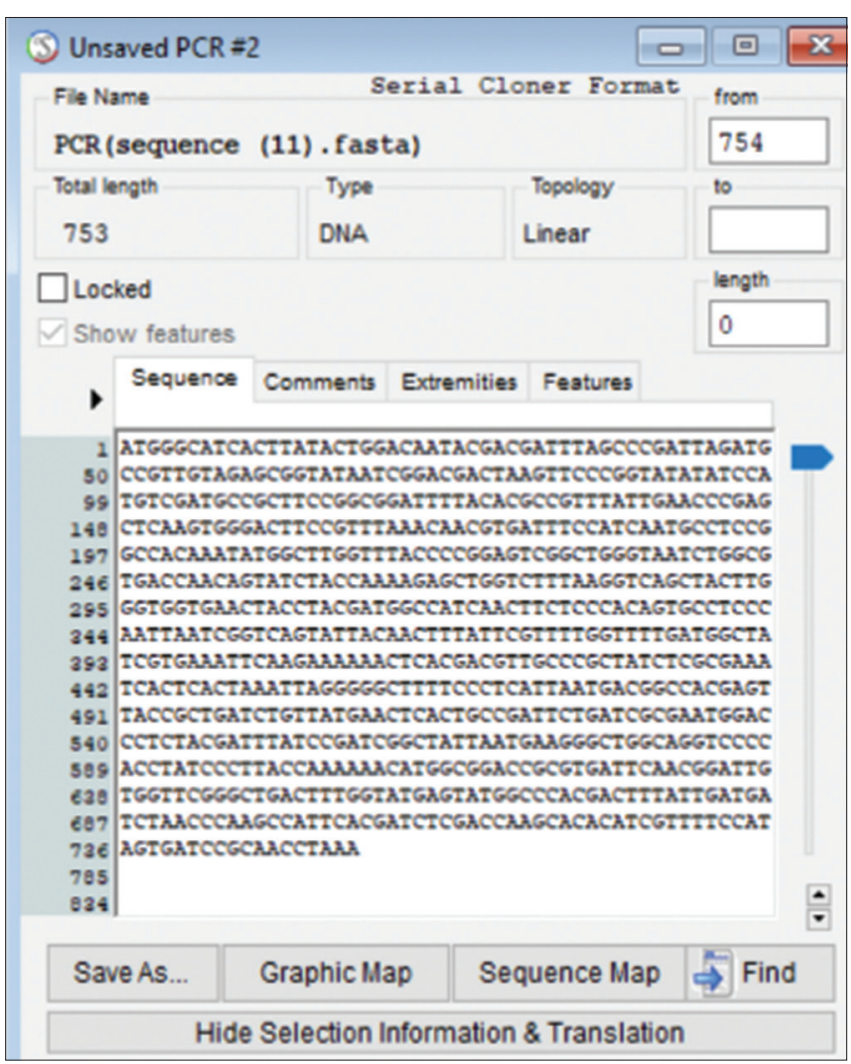

Fig. 3: Results of in silico PCR products from gad-F and gad-R1 primers

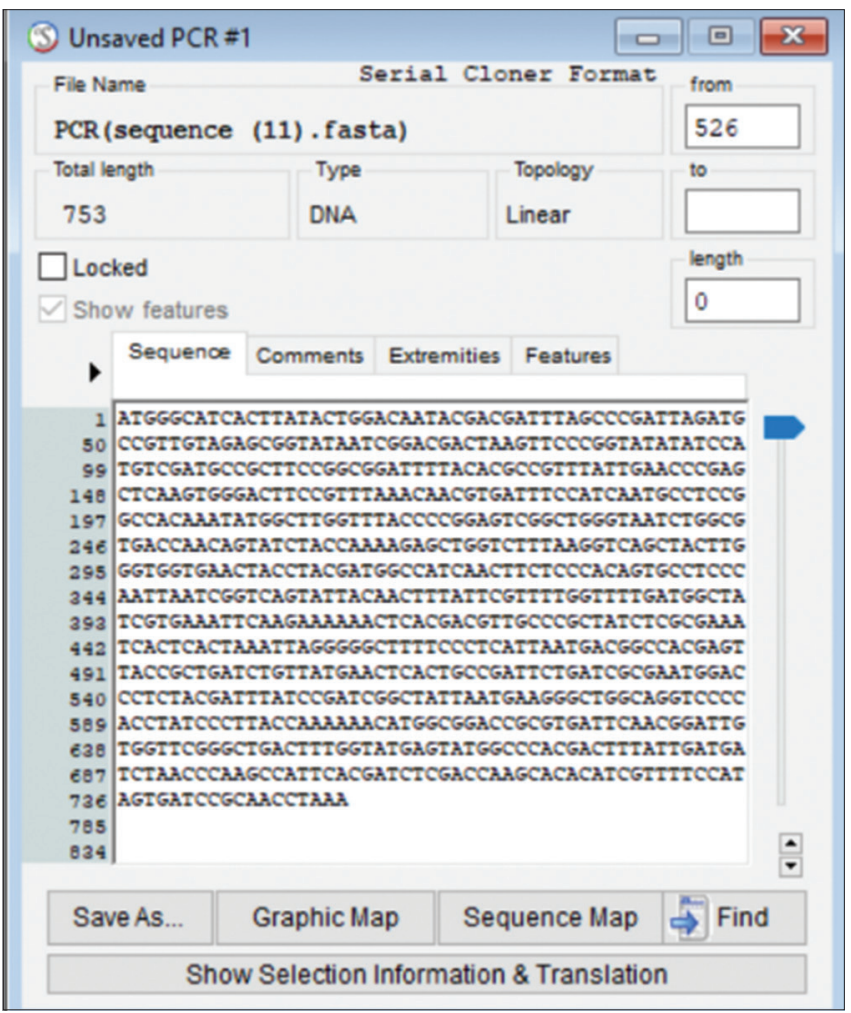

Fig. 4: Results of in silico PCR products from primers F3 and R6

template. According to Sulistyaningsih [19], the best Tm for forward and reverse primers has a range between 2 and $4^{\circ} \mathrm{C}$. Too high a Tm can result in a low PCR product.

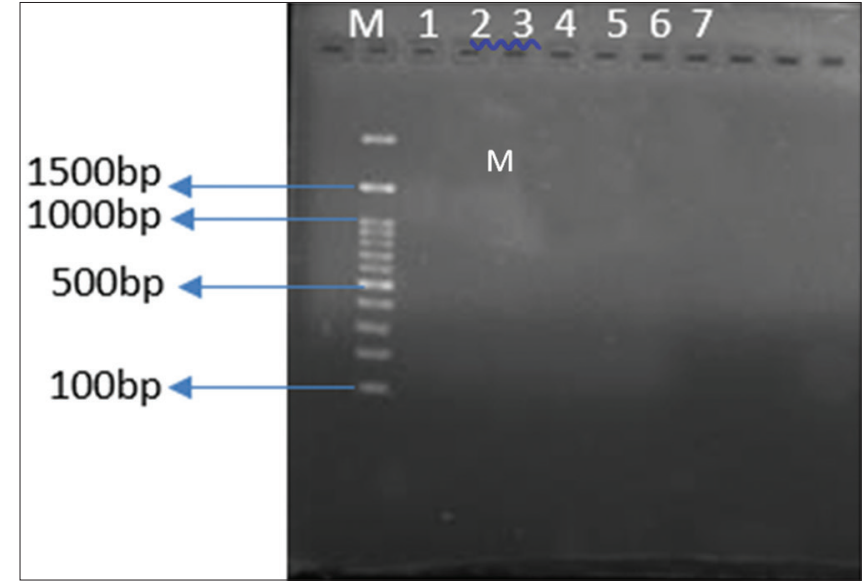

Fig. 5: Visualization of the PCR product of the gad M gene: $100 \mathrm{bp}$ marker, 1: gad-F and gad-R1, 2: gad-F and R-2, 3: F3 and R6, 4: gad-F and R6, 5: gad-F and R6, 6: F3 and gad-R1, 7: F3 and gad-R2

In addition, the cause of failure of the gad gene amplification is in the selection of bacteria in silico which is different from the identification results of the 16S rRNA coding gene. Initially, the bacteria found were thought to be bacteria from the genus Lactobacillus, but the identification of the 16S rRNA gene coding for the bacteria was obtained from the Weisella confusa species. This difference causes the designed primers to not amplify the gad gene in the genus Weissella.

\section{CONCLUSION}

LAB isolates with the highest GABA concentration, identified using $16 \mathrm{~S}$ rRNA, were similar to species Weissella confusa. Analysis based on the gad gene with several primers that had been designed, was not able to amplify the gad gene owned by $W$. confusa. The need to design specific primers according to the targeted species, by considering several good primer requirements, namely melting temperature $(\mathrm{Tm})$, percentage of G and C (\%GC), 3'dimer, stability, repeats, and hairpins.

\section{ACKNOWLEDGMENTS}

The author would like to thank the Biotechnology Laboratory and the Diponegoro University Integrated Laboratory Unit, PT. Genetics Science Indonesia and PT. Indolab Utama, Research Supervisor, my parents and friends in the Biology Faculty of Diponegoro University. The author did not get funding for this research.

\section{AUTHORS' CONTRIBUTIONS}

Adhitya Naufal Pribadhi conducts research and writes journal with help of Endang Kusdiyantini and Siti Rejeki Ferniah.

\section{CONFLICTS OF INTEREST}

The authors declare that there are no conflicts of interest.

\section{REFERENCES}

1. Achmad DI, Risa N, Puji A. Characterization of lactic acid bacteria Lactobacillus sp. RED1 from cincalok formulations. J Kim Khatulistiwa 2012;2;1-5.

2. Pangastuti A. Species definition of procaryotes based on $16 \mathrm{~S}$ rRNA and protein coding genes sequence. J Biol Divers 2006;7:292-6.

3. Kasi PD, Ariandi, Eka PT. Identification of lactic acid bacteria form Sago wastewater wirh 16S rRNA genes. Maj Ilm Biol Biosf 2019;36:35-40

4. Lee KW, Shim, JM, Yao Z, Kim JA, Kim HJ, Kim JH. Characterization of a glutamate decarboxylase (GAD) from Enterococcus avium M5 isolated from Jeotgal, a Korean fermented seafood. J Microbiol Biotechnol 2017;27:1216-22.

5. Siragusa S, Angelis MD, Cagno RD, Rizzello CG, Coda R, Gobbetti M. Synthesis of $\gamma$-aminobutyric acid by lactic acid bacteria isolated from a 
variety of Italian cheeses Appl Environ Microbiol 2007;73:7283-90.

6. Pribadhi AN, Kusdiyantini E, Ferniah RS. Isolation and characterization of lactic acid bacteria form fermented food cincalok as producer of $\gamma$-aminobutyric acid. Bioteknol Bios Indones 2020;8:25-32.

7. Walsh PS, Metzger DA, Higuchi R. Chelex 100 as a medium for simple extraction of DNA for PCR-based typing from forensic material. Biotechniques 2013;54:506-13.

8. Pelt-Verkuil EV, Belkum AV, Hays. Principles and technical aspect of PCR Amplification. Roterdam: Spinger; 2008.

9. Sambrook J, Russell D. Molecular Cloning: A Laboratory Manual. $3^{\text {rd }}$ ed. New York: Cold Spring Harbor Laboratory Press; 2001.

10. Patel J. 16S rRNA gene sequencing for bacterial pathogen identification in the clinical laboratory. Mol Diagn 2001;6:313-21.

11. Stackebrandt, E, Goebel BM. Taxonomic note: A place for DNA-DNA reassociation and 16S rRNA sequence analysis in the present species definition in bacteriology. Int J Syst Bacteriol 1994;44:846-9.

12. Hidayat P, Pancoro A. Study of molecular phulogenetics and its role in providing basic information to improve the quality of topic Orchid genetic sources. Agro Biogen 2008;4:35-40.

13. Lestari DA, Azrianingsih R, Hendrian H. Phylogenetic species of Annonaceae from east java collection of purwodadi botanical garden based on coding and non-coding DNA sequences. J Trop Biodivers Biotechnol 2018;3:1-7.

14. Fusco V, Quero GM, Cho GS, Kabisch J, Meske D, Neve H, et al. The genus Weissella: Taxonomy, ecology and biotechnological potential. Front Microbiol 2015;6:1-22

15. Thapa N, Pal J, Tamang JP. Phenotypic identification and technological properties of lactic acid bacteria isolated from traditionally processed fish products of the Eastern Himalayas. Int $\mathrm{J}$ Food Microbiol 2006;107:33-8.

16. Miyashita M, Yukphan P, Chaipitakchonlatarn W, Malimas T, Sugimoto M, Yoshino M, et al. 16S rRNA gene sequence analysis of lactic acid bacteria isolated from fermented foods in Thailand. Microb Cult Collect 2012;28:1-9.

17. Komatsuzaki N, Shima J, Kawamoto S, Momose H, Kimura T. Production of $\gamma$-aminobutyric acid (GABA) by Lactobacillus paracasei isolated from traditional fermented foods. Food Microbiol 2005;22: 497-504.

18. Borah P. Primer designing for PCR. Sci Vis 2011;11:134-6.

19. Sulistyaningsih E. Polymerase chain reaction (PCR): A new era of infectious disease diagnosis and management. Biomedis 2007;1:17-25. 